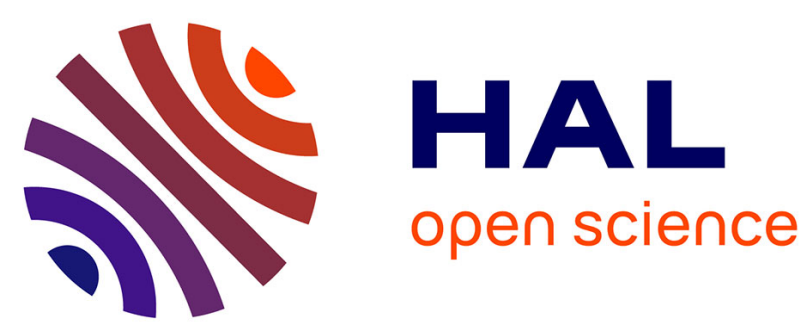

\title{
Onyx injection by direct puncture for presurgical embolization of a C2 hypervascular metastasis from a thyroid cancer
}

Frédéric Clarençon, Pierre-Emmanuel Moreau, Jonathan Cortese, Gauthier Eloy, Frédéric Deschamps, Eimad Shotar, Kevin Premat, Evelyne Cormier, Raphaël Bonaccorsi

\section{To cite this version:}

Frédéric Clarençon, Pierre-Emmanuel Moreau, Jonathan Cortese, Gauthier Eloy, Frédéric Deschamps, et al.. Onyx injection by direct puncture for presurgical embolization of a C2 hypervascular metastasis from a thyroid cancer. Journal of Neurointerventional Surgery, In press, 10.1136/neurintsurg-2020017180 . hal-03185172

\section{HAL Id: hal-03185172 \\ https://hal.sorbonne-universite.fr/hal-03185172}

Submitted on 30 Mar 2021

HAL is a multi-disciplinary open access archive for the deposit and dissemination of scientific research documents, whether they are published or not. The documents may come from teaching and research institutions in France or abroad, or from public or private research centers.
L'archive ouverte pluridisciplinaire HAL, est destinée au dépôt et à la diffusion de documents scientifiques de niveau recherche, publiés ou non, émanant des établissements d'enseignement et de recherche français ou étrangers, des laboratoires publics ou privés. 


\title{
Onyx Injection by Direct Puncture for Presurgical Embolization of a C2 Hypervascular Metastasis from a Thyroid Cancer
}

Frédéric Clarençon 1, Pierre-Emmanuel Moreau 2, Jonathan Cortese 3, Gauthier Eloy 2, Frédéric Deschamps 4, Eimad Shotar 5, Kevin Premat 6, Evelyne Cormier 5, Raphaël Bonaccorsi 2

1 Neuroradiology, Sorbonne University - Pitié-Salpêtrière Hospital, Paris, Île-de-France, France fredclare5@gmail.com.

2 Orthopedic Surgery, University Hospital Pitié Salpêtrière, Paris, Île-de-France, France.

3 NEURI-Neurointerventional Radiology, Hopital Bicetre, Le Kremlin-Bicetre, France.

4 Interventional Radiology, Institut Gustave-Roussy, Villejuif, Île-de-France, France.

5 Neuroradiology, Pitié-Salpêtrière University Hospital, Paris, France.

6 Neuroradiology, Sorbonne University - Pitié-Salpêtrière Hospital, Paris, Île-de-France, France.

\begin{abstract}
Surgery of spine hypervascular lesions, like hemangioma or metastases from thyroid or renal cancer may be very challenging due to the risk of massive blood loss. ${ }^{1}$ To overcome this limitation, presurgical embolization has gained acceptance to reduce this risk. ${ }^{2}$ However, some configurations, like the origin of a radiculomedullary artery close to the vessels feeding the lesion, or when the lesion is supplied by vessels feeding an eloquent territory, may limit the possibilities of presurgical embolization, especially with microparticles. ${ }^{3}$ Direct percutaneous puncture of the spine lesion and subsequent embolization with liquid agent may be a valuable option in such challenging cases. ${ }^{4}$

We present herein a case of presurgical embolization of a C2 metastasis from a thyroid cancer using Onyx-18 injected by direct puncture (Video 1). We stress in this Technical Video the technical aspects of the direct puncture technique and the safety rules to avoid neurological complications.
\end{abstract}




\section{References}

1. Sundaresan N, Choi IS, Hughes JE, Sachdev VP, Berenstein A. Treatment of spinal metastases from kidney cancer by presurgicalembolization and resection. $J$ Neurosurg. 1990;73(4):548-54. doi: 10.3171/jns.1990.73.4.0548.

2. Ashour R, Aziz-Sultan A. Preoperative tumor embolization. Neurosurg Clin N Am. 2014 ;25(3):607-17. doi: 10.1016/j.nec.2014.04.015.

3. Oppermann J, Bredow J, Siewe J, Eysel P, Koy T. Hypervascular cervical spine metastases: embolization by direct injection of Onyx-18. Eur Spine J. 2015;24 Suppl 4:S580-4. doi: 10.1007/s00586-014-3754-4.

4. Clarençon F, Di Maria F, Cormier E, et al. Onyx injection by direct puncture for the treatment of hypervascular spinal metastases close to the anterior spinal artery: initial experience. J Neurosurg Spine. 2013;18(6):606-10. doi: 10.3171/2013.3.SPINE12832. 